\title{
SRAS-CoV-2 ET LES ANIMAUX DOMESTIQUES
}

\section{Soraya Abrantes Pinto de Brito ${ }^{1}\left(\mathbb{1} ;\right.$; Gil Dutra Furtado ${ }^{2}$; Magnolia Ouriques de Oliveira ${ }^{3^{*}}$}

\section{Abstrait}

Les CoV (coronavirus) appartiennent à la des virus de l'acide ribonucléique (ARN) et sont connus sous le nom de coronavirus parce que la particule virale a une caractéristique « couronne ». Les infections au CoV sont courantes chez les humains et les animaux, dont certaines sont zoonotiques. Le CoV peut provoquer des pathologies allant du rhume à des maladies plus graves, telles que le syndrome respiratoire du Moyen-Orient (causé par le MERS-CoV) et le syndrome respiratoire aigu sévère (causé par le SRAS-CoV) chez l'homme. Certains travaux scientifiques montrent que le SRAS-CoV a été transmis des civettes aux humains et le MERS-CoV des dromadaires aux humains. Le CoV qui cause le COVID-19 a été nommé SARS-CoV2 par le Comité international de taxonomie des virus (ICTV). Selon la recherche scientifique, les preuves actuelles suggèrent que le SRAS-CoV-2 a émergé d'une source animale, et les informations sur la séquence génétique révèlent que le SRASCoV-2 est similaire à d'autres CoV trouvés dans les populations de chauves-souris fer à cheval (Rhinolophus Ferrumequinum). Pas encore assez de preuves scientifiques pour mettre en évidence la source réelle du SRAS-CoV-2 ou pour expliquer quelle était la voie initiale de transmission de celui-ci aux humains (qui peut avoir impliqué un hôte intermédiaire). Étant donné que l'infection par le SRAS-CoV-2 est si largement répandue dans la population humaine, on observe qu'il est possible que certaines espèces animales soient infectées par contact avec des humains infectés. Les animaux infectés par le SRAS-CoV-2 peuvent créer des situations inattendues pour la santé animale et humaine, ainsi que pour le bien-être animal, la préservation de la faune et la recherche biomédicale. Quant aux animaux domestiques tels que les chats et les chiens, ils ont été testés positifs pour le SRAS-CoV-2 après avoir eu des contacts avec des êtres humains infectés par ce virus. Au cours des travaux d'observation réalisés avec ces animaux, les chats ont présenté des signes cliniques de la maladie tels que des problèmes respiratoires et gastro-intestinaux. Bien qu'il ait été confirmé que des animaux ont été infectés par le SRAS-CoV-2, il n'est pas confirmé, à ce jour, que ces animaux aient transmis le COVID 19 à l'homme, mais il est bien observé que la pandémie est due à la transmission de l'homme à l'homme. Comme les animaux et les humains peuvent être affectés par ce virus zoonotique, il est recommandé aux personnes suspectées ou confirmées d'infection par le SRAS-CoV-2 de limiter le contact avec leurs animaux de compagnie.
1 Académie à la Faculté Maurício de Nassau, cours de médecine vétérinaire, João Pessoa - PB Brésil.

2 Docteur en PSYCHOBIOLOGIE; Académicien à la Faculté Mauricio de Nassau, cours de médecine vétérinaire, João Pessoa - PB Brésil.

${ }^{3}$ Cadre Medico Educatif, Educatrice Spécialisée, Monitrice Educatrice, Aide Medico Psychologique / Institut Régional du Travail Social, Poitiers, France (IRTS). * Auteur correspondant. Courriel: sorayabrito1970@hotmail.com

Mots clés: COVID 19. SARS-CoV-2. Chiens et chats. 


\section{Resumen}

Los CoV (coronavirus) pertenecen a los virus del ácido ribonucleico (ARN) y se conocen como coronavirus porque la partícula del virus tiene una característica de "corona". Las infecciones por CoV son comunes en los seres humanos y en los animales, algunos de los cuales son zoonóticos. El CoV puede causar desde un resfriado común hasta enfermedades más graves, como el síndrome respiratorio de Oriente Medio (causado por el MERS-CoV) y el síndrome respiratorio agudo severo (causado por el SARS-CoV) en humanos. Hay algunas pruebas científicas de que el SARS-CoV se ha transmitido de las civetas a los humanos y el MERS-CoV de los camellos a los humanos. El Comité Internacional de Taxonomía de Virus (ICTV) ha denominado al CoV que causa el COVID-19 como SARS-CoV-2. Según la investigación científica, las pruebas actuales sugieren que el SARS-CoV-2 surgió de una fuente animal, y la información de la secuencia genética revela que el SARS-CoV-2 es similar a otros CoV encontrados en poblaciones de murciélagos de herradura (Rhinolophus Ferrumequinum). Todavía no hay suficientes pruebas científicas para determinar el origen real del SARS-CoV-2 ni para explicar cuál fue la vía inicial de transmisión a los humanos (que puede haber implicado a un huésped intermedio). Dado que la infección por el SRAS-CoV-2 está tan extendida en la población humana, es posible que algunas especies animales se infecten por contacto con personas infectadas. Los animales infectados por el SARS-CoV-2 pueden crear situaciones inesperadas para la salud animal y humana, el bienestar de los animales, la conservación de la fauna salvaje y la investigación biomédica. Los animales domésticos, como los gatos y los perros, han dado positivo en las pruebas de detección del SRAS-CoV-2 tras haber estado en contacto con personas infectadas por el virus. Durante el trabajo de observación de estos animales, los gatos mostraron signos clínicos de la enfermedad, como problemas respiratorios y gastrointestinales. Aunque se ha confirmado que los animales se han infectado con el SARS-CoV-2, hasta la fecha no se ha confirmado que estos animales hayan transmitido el COVID 19 a los seres humanos, pero se ha observado que la pandemia se debe a la transmisión de persona a persona. Dado que tanto los animales como los seres humanos pueden verse afectados por este virus zoonótico, se recomienda que las personas con infección sospechosa o confirmada por el SARS-CoV-2 limiten el contacto con sus mascotas.

Palabras clave: COVID 19. SARS-CoV-2. Perros y gatos.

\section{Abstract}

CoVs (coronaviruses) belong to the ribonucleic acid (RNA) viruses and are known as coronaviruses because the virus particle has a "crown" characteristic. CoV infections are common in humans and animals, some of which are zoonotic. CoV can cause conditions ranging from the common cold to more serious diseases, such as Middle East Respiratory Syndrome (caused by MERS-CoV) and Severe Acute Respiratory Syndrome (caused by SARS-CoV) in humans. Some scientific work shows that SARS-CoV was transmitted from civets to humans and MERS-CoV from dromedaries to humans. The CoV that causes COVID-19 has been named SARS-CoV-2 by the International Committee on Taxonomy of Viruses (ICTV). According to scientific research, current evidence suggests that SARS-CoV-2 emerged from an animal source, and genetic sequence information reveals that SARSCoV-2 is similar to other CoVs found in horseshoe bat (Rhinolophus Ferrumequinum) populations. There is not yet enough scientific evidence to pinpoint the actual source of SARSCoV-2 or to explain what the initial route of transmission of SARS-CoV-2 to humans was (which may have involved an intermediate host). Because SARS-CoV-2 infection is so widespread in the human population, it is possible that some animal species may become infected through contact with infected humans. Animals infected with SARS-CoV-2 can create unexpected situations for animal and human health, as well as for animal welfare, wildlife conservation and biomedical research. Domestic animals such as cats and dogs have tested positive for SARS-CoV-2 after contact with humans infected with the virus. During observational work with these animals, the cats showed clinical signs of the disease such as respiratory and gastrointestinal problems. Although it has been confirmed that animals have been infected with SARS-CoV-2, it is not confirmed at this time that these animals have transmitted COVID 19 to humans, but it is well observed that the pandemic is due to human-to-human transmission. As both animals and humans can be affected by this zoonotic virus, it is recommended that people suspected or confirmed of having SARS-CoV-2 infection limit contact with their pets.

Keywords: COVID 19. SARS-CoV-2. Dogs and cats. 